\title{
Analysis of farmers' perceptions and behavioral response to rural living environment renovation in a major rice-producing area: a case of Dongting Lake Wetland, China
}

\section{Zhenghua Deng $^{1 *}$ Liqi Dai ${ }^{1}$ Liping Deng ${ }^{1}$ (D) Pingfeng Peng ${ }^{1}$ (iD}

${ }^{1}$ School of Economics and Management, Hunan Institute of Science and Technology, Yueyang, Hunan, China. E-mail: 995469629@qq.com. ${ }^{*}$ Corresponding author.

ABSTRACT: This article combines influencing factors of farmers' participation in the Rural Living Environment Renovation Project (RLERP) and conceptualizes a model that depicts the relationships between the demographic characteristics of farmers and their perceptions and behavioral response to RLERP. Using a questionnaire survey to collect empirical data, we found (1) A total of $92 \%$ of farmers have fully realized the importance of rural living environment, but most people have adopted a wait-and-see attitude and a lack of motivation to participate. (2) A total of $65 \%$ of farmers participate in the collection and classification of domestic waste, 22\% of the farmers participate in captivity livestock behavior, and 19\% of farmers participate in the response behavior of domestic sewage treatment. (3) A significant positive correlation occurs between income level and farmers' cognition and behavior response. (4) The education standards of the public are not correlated with the farmers' cognition but is significantly correlated with farmers' behavioral response. (5) The cognitive and behavioral response of females to RLERP is significantly higher than that of men. 6) In the process from cognition to the action response, farmers' cognition is positively correlated with action response. On this basis, some measures and suggestions to improve the response of farmers to rural living environment renovation are put forward.

Key words: rural living environment renovation, farmers 'perceptions, behavioral response, Dongting Lake.

Análise das percepções dos agricultores e resposta comportamental à renovação do ambiente de vida rural em uma grande área de produção de arroz: Um caso de Dongting Lake Wetland, China

RESUMO: Este artigo combina fatores que influenciam a participação dos agricultores no Projeto de Renovação do Ambiente Rural (RLERP) e conceitua um modelo que descreve as relações entre as características demográficas dos agricultores e suas percepções e resposta comportamental ao RLERP. Usando uma pesquisa por questionário para coletar dados empíricos, encontramos: (1) um total de 92\% dos agricultores perceberam plenamente a importância do ambiente de vida rural, mas a maioria das pessoas adotou uma atitude de esperar para ver e uma falta de motivação para participar; (2) um total de 65\% dos agricultores participam da coleta e classificação do lixo doméstico, $22 \%$ dos agricultores participam do comportamento pecuário em cativeiro e 19\% dos agricultores participam do comportamento de resposta ao tratamento de esgoto doméstico; (3) uma correlação positiva significativa ocorre entre o nível de renda, a cognição e a resposta comportamental dos agricultores; (4) os padrões de educação do público não estão correlacionados com a cognição dos agricultores, mas estão significativamente correlacionados com a resposta comportamental dos agricultores; (5) a resposta cognitiva e comportamental das mulheres ao RLERP é significativamente maior do que a dos homens; (6) no processo de cognição para resposta de ação, a cognição dos agricultores está positivamente correlacionada com a resposta de ação. Com base nisso, são apresentadas algumas medidas e sugestões para melhorar a resposta dos agricultores à renovação do ambiente rural.

Palavras-chave: renovação do ambiente rural, percepções dos agricultores, resposta comportamental, Dongting Lake.

\section{INTRODUCTION}

The Dongting Lake Wetland Reserve is located in the middle reaches of the Yangtze River in China. The reserve mainly covers 3 cities and 16 counties (urban areas) of Yueyang, Changde, and Yiyang. It has a rural population of 7.1 million and a per capita arable land area of 0.65 hectares. As the main traditional rice production area in China, the reserve enjoys the reputation of being the "land of fish and rice." The reserve is an important production and export base of commercial grains in the country, and it is also a key area for China's new rural construction. However, affected by the traditional concept of "treatment after pollution," rural environmental management is relatively lagging, infrastructure construction is insufficient, rural settlements are scattered, and rural household garbage, livestock manure, and domestic sewage have seriously affected farmers' production, lives, 
and village appearance. Agriculture is a significantly important economic sector in China (QI et al., 2018), and greening is an inevitable trend of future agricultural development (LIU et al., 2018). Thus, the policy of rural environment renovation in the Dongting Lake Wetland Reserve is of considerable importance for promoting the transformation of agricultural ecology and green development.

Recently, the importance of rural environmental protection has been recognized by the Chinese government, and environmental legislation and policy regulations to promote public participation have been increasing (TANG et al., 2008). In 2016, the Chinese central government proposed to implement the RLERP in Dongting Lake wetland and required governments at all levels to be responsible for implementing the rural living environment renovation in their jurisdictions. The RLERP controls the diffusion of rural domestic pollution such as household waste, sewage, and livestock dung. The program must be implemented from a point to an entire area, and substantial progress must be made within three years.

Although, government departments dominate China's rural environmental renovation, the implementation effect of RLERP is not as effective as is expected (XIE, 2016) because farm households have become the main body for management and production in rural areas and the basic unit of decision-making. Their attitude toward environmental protection may affect the rural eco-environment in different ways and to various degrees. Therefore, cognition and behavioral response of farmers to rural environmental remediation will affect the development direction of the rural environment.

Farmer's participation is crucial for RLERP. Individual cognition is the basis of their behavioral decision-making (SULLIVAN, XIE, 2009). Thus, farmers' cognition of rural environmental renovation are the internal driving force for them to participate in RLERP (AJZEN, 1991; AJZEN, 2011). Furthermore, RLERP may not change farmers' behavior if their perceptions do not change; the farmer's cognitive level directly affects his behavioral response. According to Marr and Howley, individuals' environmental cognition is affected by factors such as income and level of education (MARR, E.J; HOWLEY, P. 2019). Farmers have varying cognition toward RLERP, and their behavioral responses are different, ranging from inaction or irresponsible behavior to proactive environmental action (HEBERER, 2009).
A farmer's RLERP behavior can be regarded as activities in which the farmer is engaged to protect the agricultural environment during daily life, such as garbage classification, sewage treatment, and livestock captivity (BELL et al., 2016). This behavior is affected by many factors, such as farmers' degrees of environment cognition, subjective norms, and governments' environmental regulations (Wang et al., 2019). As indicated in a recent survey, despite rising environmental awareness, many farmers are unwilling to make the required changes to live an improved lifestyle. Thus, non-response is the general attitude of farmers to participate in rural living environment renovation (KOSTKA, 2013).

The analysis of the mechanism of farmers' cognition on their behavior response in RLERP can guide farmers to participate in a beautiful countryside construction and provide an important reference for devising policies for the RLERP. However, many scholars believe that some demographic and socioeconomic factors might be the dominant reasons that hinder farmers from conducting RLERP (LU, XIE, 2018). However, clear evidence to understand why and how farmers were willing to engage in RLERP remains lacking (MORAIS, BORGES, et al., 2018). For example, previous scholars simply analyzed the connotation of environmental protection awareness, the relationship between farmers' environmental awareness, and rural environmental renovation; these studies conducted no quantitative analysis (ZHOU JIN, 2009; LV JUN, 2008; ZHU QIZHEN, 2001; GU XINMEI, 2008). Therefore, from the perspective of empirical and quantitative analysis, an in-depth study of farmers' willingness to participate in RLERP and factors that affect farmers' cognition has important practical significance for promoting a beautiful countryside construction.

Government supervision, economic incentives, and farmers' cognitive level are factors that affect farmers' behavioral decisions (MAO CHENGXING, 2018). Studies indicated that the influencing factors of farmers' cognition and adoption of ecological agricultural technology include farmers' factors and external environmental factors (HUANG JIJUN, 1999; KONG XIANGZHI, 2004; HU RUIFA, 2004). According to the ABC theory of predicting environmental behavior proposed, environmental behavior is the result of the interaction between personal attitude and external conditions (GUAGNANO et al., 1995). Therefore, this study conceptualizes farmer behavior as a product of the external factors to which farmers are exposed and individual characteristics held by farmers. The 
external factors included popular science propaganda and interpersonal communication. Internal characteristics include factors such as age, gender, economic status, and education level. Internal and external factors work together to make farmers have different cognition levels about the RLERP, after being affected by government supervision, group behavior, and infrastructure. Different cognition levels directly affect the behavioral responses of farmers when participating in RLERP. However, the behavior of farmers is not only directly affected by farmers' cognition. External conditions such as government policies, the construction of environmental protection public facilities, and collective behavior are all significant factors that affect farmers' participation in the remediation of rural human settlements. Thus, farmers in different cognitive degrees have different behavioral responses.

By examining how human cognition shapes behavior, this paper constructs a conceptual framework (Figure 1). A combination of stratified sampling and random sampling was used to conduct surveys and visits on 480 farmer households in six villages. The ratio method and mono-factor regression analysis method were used to statistically analyze the survey results, analyzing age, gender, income, and education with respect to the degree of impact on farmers' participation in RLERP and the relationship between farmers' cognition and behavioral responses.

The remainder of this paper is organized as follows. Section 2 introduces the materials and methods. Section 3 presents the empirical analysis and results. Section 4 discusses the research findings and concludes the study.

\section{MATERIALS AND METHODS}

\section{Survey areas and questionnaire design}

This survey began in the core area of the major rice-producing areas of Dongting Lake wetland. The researchers visited six villages of five counties in the East and West Dongting Lake regions. The samples were chosen by stratified stepwise and random sampling. Three samples from East Dongting Lake and two samples from the West Dongting Lake region were chosen. A total of 480 questionnaires were distributed, and 450 valid samples were obtained, accounting for $92.5 \%$ of the total samples (Table 1). To ensure data quality, the survey was strictly involved in the investigation procedure. 8 teachers and 65 undergraduates from the Research Institute of Dongting Lake Ecological Economic

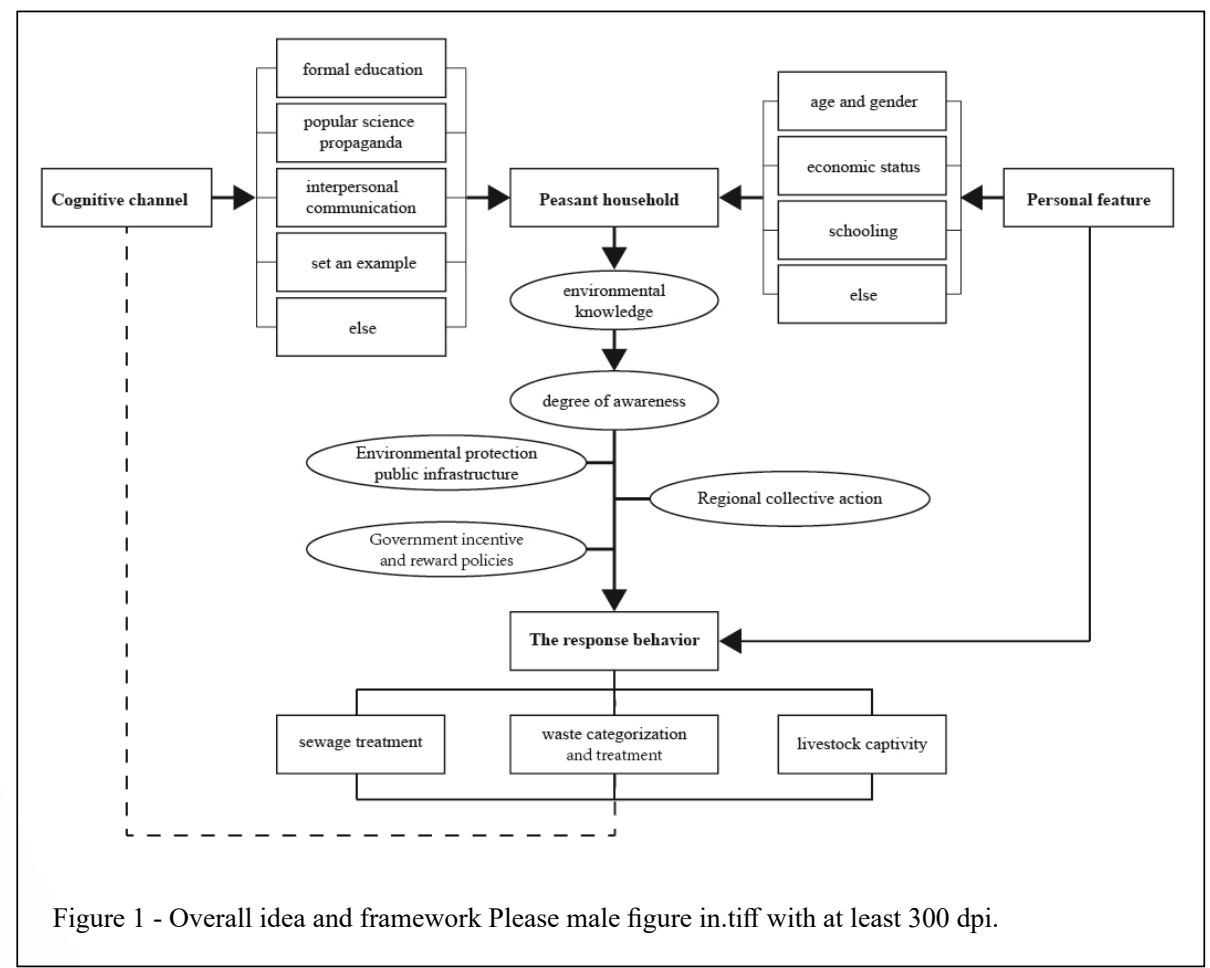

Ciência Rural, v.51, n.5, 2021. 
Table - 1 Survey areas and valid questionnaires.

\begin{tabular}{|c|c|c|c|c|}
\hline Region & County & Village & $\begin{array}{c}\text { Questionnaire } \\
\text { amount }\end{array}$ & $\begin{array}{c}\text { Percentage } \\
(\%)\end{array}$ \\
\hline \multirow{4}{*}{ East Dongting Lake region } & Huang County & Shown Puxian Village & 78 & 17 \\
\hline & & Sanfengshi Town Fuxing Village & 75 & 17 \\
\hline & Junshan County & Caishanghu Town Yandun Village & 82 & 18 \\
\hline & Yueyang County & Zhongzhou Country Tiandeng Village & 62 & 14 \\
\hline \multirow{2}{*}{ West Dongting Lake region } & Li County & Guanwan Country Haokou Villages & 78 & 17 \\
\hline & West Dongting Lake Farm & Zhufeng Town Tuanjie Village & 75 & 17 \\
\hline
\end{tabular}

Zone, Hunan Institute of Science and Technology conducted two-week training on rural participatory survey and designed a unified market research plan book and questionnaire in June 2018. Under the strong support of the agriculture department and the sample towns and village leaders, the teachers led the students in conducting special investigations in sample villages. During the investigation, we lived in the farmers' homes, required the students to immerse in the villages, and had a harmonious relationship with farmers and disseminated the questionnaires. We adhered to the following rules during the investigation. (1) The surveyed farmers' genders, ages, and education levels should be kept in relative proportions. (2) Investigators should pay a return visit to key farmers in each village in 1-2 days to add and modify data. The data were also encoded in a database by the student interviewers, proofread by the author, and sampled for verification. All data in the article were obtained from the raw surveyed data. In addition to a few live interviews, this research mainly relies on questionnaires (shown in supplementary data) to collect the data. Based on the analytical framework shown in figure 1, a unified structured questionnaire was designed and divided into three parts. The first part included the surveyed farmers' basic information, including age, gender, income level, and education degree. The second part comprised the farmers' perceptions of the RLERP, including farmers' view of the rural environment and the cognition degree of RLERP. The third part addressed the farmers' behavior in response to the rural living environment comprehensive renovation, mainly including waste categorization and initiative collection, livestock captivity, and domestic sewage treatment. It investigated the various actions of surveyed farmers toward rural living environment renovation. These parts were related to one another and reflected the farmers' perceptions about the importance of the rural living environment and their response to the renovation action in the survey area.

\section{Data processing and variable assignment}

The meaning and value assignment for the main variables are as follows. (1) The living environment awareness variable V1 describes the effect on the lives of farmers and rural life environmental pollution in the survey area and recognizes that a neat living environment and village appearance benefit the farmer's production and life. Farmers who can gain $\mathrm{V}_{1}$ a value of 1 , whereas farmers who cannot identify or have no feeling gain a value of 0 . (2) The living environmental renovation skill variable $\mathrm{V}_{2}$ : describes the farmers' familiarity with living environment improvement skills and the rural living environment renovation policy and principles and their knowledge about comprehensive renovation of the rural living environment. Farmers whose answer is "known" can gain a value of 1, whereas those whose answer is "unknown" gain a value of 0 . (3) The waste categorization and collection variable: $\mathrm{V}_{3}$ to describes farmers' initiative and attitude to categorize and collect waste. Farmers who actively participate after being encouraged by others' actions or government policy incentives gain a value of 1 . Farmers whose conditions are unripe, and those who are not prepared to gain a value of 0 . (4) Livestock captivity behavior variable: $V_{4}$ to describe the behavior and attitudes of the survey area farmers for livestock captivity. Farmers who actively participate after being encouraged by others' actions or government policy incentives gain a value of 1 . Farmers whose conditions are not mature and those who are not prepared to gain a value of 0. (5) Domestic sewage treatment behavior variable: $\mathrm{V}_{5}$ to describe the behavior and attitudes of the survey area farmers for kitchen and laundry sewage treatment. Farmers who actively participate after being encouraged by 
others' actions or government policy incentives gain a value of 1 . Farmers whose conditions are not mature and those who are not prepared to gain a value of 0 . (6) The farmers' response behavior on the RLERP variable: $\mathrm{V}_{6}$ comprehensively describes the degree of farmers' participation for the rural living environment renovation project, which can be calculated as $\mathrm{V}_{6}=\mathrm{V}_{3}+\mathrm{V}_{4}+\mathrm{V}_{5} / 3$.

\section{Mathematical analysis methods}

In the ratio method, the aim is to analyze the cognition and participation degree of the sample farmers in the survey area on the RLERP. The questionnaire score of each variable under the best conditions is the ideal score, which represents the best level of the surveyed farmers' perceptions and behavioral response to the RLERP. The variables are, $\mathrm{V}_{1}, \mathrm{~V}_{2}, \mathrm{~V}_{3}, \mathrm{~V}_{4}, \mathrm{~V}_{5}$, and $\mathrm{V}_{6}$, where $\mathrm{V}_{1=} \mathrm{V}_{2=} \mathrm{V}_{3=} \mathrm{V}_{4=} \mathrm{V}_{5=} \mathrm{V}_{6=1}$. The scoring rate of the sample variable is equal to the total value of each variable for each sample divided by their best score of variables. The rate represents the practical abilities of the sample farmers' perceptions and behavioral response to the RLERP. A higher scoring rate represents better abilities based on perceptions and behavioral response.

2. Mono-factor regression analysis is used to study the relationship between demographic characteristics (internal factors), such as age, gender, education, and family income farmers' cognition and action response in the RLERP. Then, the effect of farmers' cognitive level is discussed.

\section{The descriptive analysis of the whole sample}

For basic characteristics of the surveyed farmers (Table 2), from the perspective of gender, $44.1 \%$ were male and $55.9 \%$ were female. The age of surveyed farmers ranges from 13-74. A total of 248 farmers aged 35-55 years, approximately accounting for $53 \%$ of the total samples, whereas 94 farmers are aged $55-65$, accounting for $20 \%$ of the total samples. The rural population age trend is very obvious. The education level of farmers is mainly primary and junior high school, accounting for $97 \%$ of the total sample. More than seven farmers attained junior college or above. Five of them were principally engaged in the commercial and service field in the rural area. The farm household income was the total income of farm households. The investigators asked the respondents to fill in the total household income, including the income from rice cultivation and other sources.

\section{DATA ANALYSIS AND RESULTS}

Farmers' perceptions and response degree to the rural living environment renovation project

In the investigation of farmers' living environmental awareness, the total score of sample farmers' living environment awareness is, $\sum \mathrm{V}_{1}=418$

Table 2 - Statistics of respondents' population characteristics.

\begin{tabular}{|c|c|c|c|c|}
\hline Features & Groups & \multicolumn{2}{|c|}{ Regions } & Total (\%) \\
\hline & \multicolumn{4}{|c|}{---------East West-------- } \\
\hline \multirow{2}{*}{ Gender } & Male & 135 & 68 & $203(44.1)$ \\
\hline & Female & 162 & 85 & $247(55.9)$ \\
\hline \multirow{4}{*}{ Age } & $<15$ & 12 & 7 & $19(4.2)$ \\
\hline & $15-35$ & 39 & 19 & $48(10.7)$ \\
\hline & $35-55$ & 166 & 82 & $248(52.7)$ \\
\hline & $\cdot 55$ & 80 & 66 & $146(32.4)$ \\
\hline \multirow{4}{*}{ Education level } & Primary school & 144 & 72 & $218(48.5)$ \\
\hline & Junior high & 123 & 70 & $193(42.3)$ \\
\hline & Senior high & 25 & 7 & $32(7.2)$ \\
\hline & College and above & 5 & 2 & $7(1.6)$ \\
\hline \multirow{4}{*}{ Household income level } & Under $\$ 2882.69$ & 21 & 12 & $33(7.3)$ \\
\hline & $\$ 2882.69-\$ 8648.06$ & 179 & 98 & $277(61.7)$ \\
\hline & $\$ 8648.06-\$ 11530.75$ & 67 & 28 & $95(21.0)$ \\
\hline & Above $\$ 11530.75$ & 30 & 12 & $42(9.3)$ \\
\hline
\end{tabular}

Ciência Rural, v.51, n.5, 2021. 
and the score ratio of the living environment awareness of the farmers is 0.92 , indicating that $92 \%$ of the farmers believed that the rural living environment and village appearance should be improved. They realized that a good environment benefits them. This finding also suggested that the farmers recognize that rural living environment pollution affected their life and village appearance. Furthermore, a neat living environment and village appearance benefited their production and life. This result implied the necessity of RLERP. In accordance with the government's appropriate policies and measures on the living environment renovation, farmers will likely support and actively respond to the renovation project of the rural life environment.

The total score of the sample farmers' perceptions to the rural living environment renovation policies and skills is $\sum \mathrm{V}_{2}=126$, and the score ratio of farmers to the rural living environment policy and living environmental renovation skills is 0.28 , indicating that only $28 \%$ of the farmers thought that they had a basic understanding of the government's rural living environment comprehensive renovation policy or the means to improve the rural living environment. The results showed that farmers' familiarity with the government's policy of comprehensive renovation of rural environment and the necessary renovation skills are far from ideal. The whole score of farmers' behavioral response to rural waste collection and categorization is $\sum V_{3}=292$ , and the score ratio of the farmers' a behavioral response to waste collection and categorization is
0.65. The data are obviously higher than the total score $\left(\sum \mathrm{V}_{4}=99\right)$ of farmers' behavioral response to livestock captivity with a score ratio of 0.19 . The total score of farmers' behavioral response to domestic sewage treatment is $\sum V_{5}=85$ with a score ratio of 0.19 (Figure 2). This finding indicates the farmers' belief that domestic waste is the main pollution source that affects the village appearance. As long as the government guides the farmers properly, most of them will change their behavior of discarding garbage casually around their house and encourage them to actively participate in their own waste collection and treatment. Therefore, group cleaning, village collection, town compression, and county processing in main places are acceptable measures.

The degree of farmers' sewage treatment behavioral response is the lowest. During the interview, most farmers thought that they did not know how to process domestic sewage. They are accustomed to dumping sewage directly in minor grooves or in front of their own house, whereas a small part of farmers who participated in domestic sewage treatment only used specialized pipelines to discharge sewage in the drains around their houses. The scoring ratio of farmers' behavioral response to livestock captivity is relatively low, and most farmers thought that livestock feces pollutes the environment. However, livestock is not suitable for captivity, which is laborious and time-intensive. They expressed that they would raise but not rear livestock in pens. Therefore, affected by the traditional concept, habits, and response cost, the

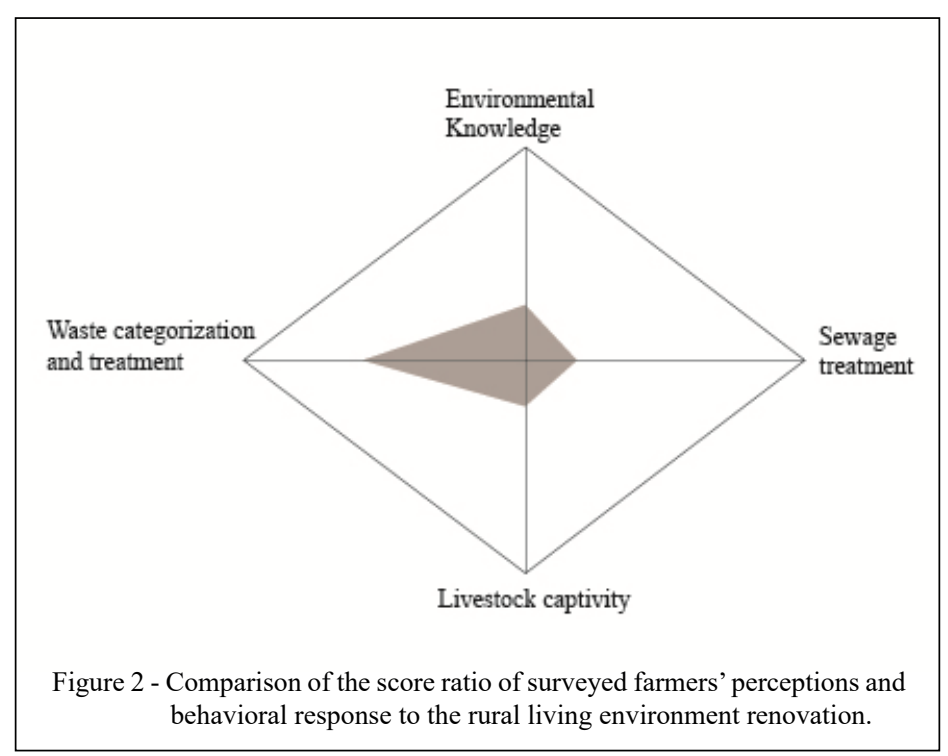

Ciência Rural, v.51, n.5, 2021. 
farmers have a low level of response to rural sewage treatment and livestock captivity.

\section{Group differences in farmers' perceptions and behavioral response}

1). Age differences. The respondents were classified into different segments according to age: under 15, 15-60, and over 60 . The average score ratio of farmers to the four variables of rural living environment knowledge, waste categorization, and collection, livestock captivity, and domestic sewage treatment at different age stages were calculated. The results show that the comprehensive scoring ratio of the four variables for the 35-55-year-old segment has an upward trend and present the highest point (Figure 3 ). This observation may be due to the combined effects of several factors. (1) The age segment under 15 years old is the golden period of learning, in which farmers studied general knowledge about environmental health and the prevention and treatment of infectious diseases, allowing them to fully recognize the importance of sanitation. However, they have not fully understood the policies and skills for the comprehensive renovation of the rural living environment. Farmers who are over 50 years old have rich life experience but do not have sufficient awareness of the importance of living environment health; their mode of thinking is relatively rigid and not sensitive to external things. (2) Farmers aged 3555 years constitute the main force in the construction of the rural economy and society. Most of them are party members and able men that play an important role in family and social life in rural areas and serve as vanguards of government policy implementation. The degree of perceptions and response to the rural environment renovation was significantly higher than those of other groups.

2). Gender differences. The average score ratio of the four variables of rural living environment comprehensive renovation policies, skill perceptions, waste categorization, and the concentrated behavior of livestock captivity and sewage treatmentwerecalculated in male and female farmers. Simultaneously, the four variables were tested (t-test) according to gender mean differences. Results showed that the score ratio of male and female farmers did not differ significantly on the perceptions of rural living environment comprehensive renovation and did not meet the set and obvious level at $\alpha=0.1$ (Table 3). Female farmers' score rate on the behavior on waste categorization, livestock captivity, and sewage treatment were obviously higher than that of male farmers. Given that women undertake the main household housework, which is the main body of the rural living environment renovation, policy advocacy and implementation in the future should focus on the status and role of rural women.

3). Education levels. To analyze the relationship between rural living environment comprehensive renovation policies, skill perceptions, waste categorization, concentrated behavior of livestock captivity, and education level. The comprehensive score ratio of the four variables was obtained at different education levels. Inputting the related date into SPSS 17.0, the results showed

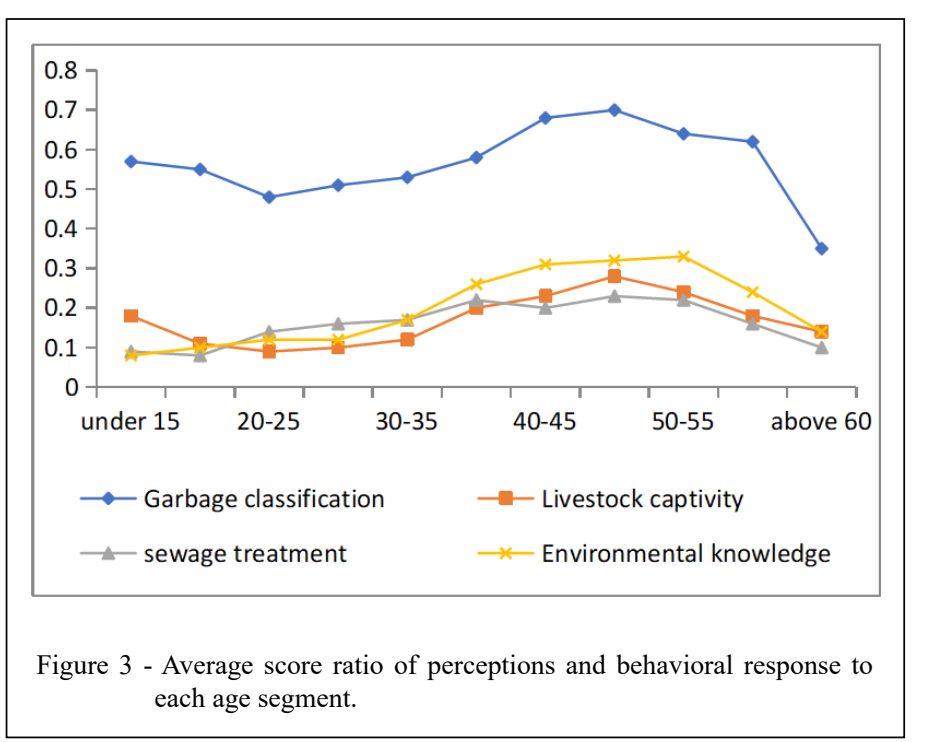

Ciência Rural, v.51, n.5, 2021. 
Table 3 - Average score ratio of each variable in different gender and difference test (t-test).

\begin{tabular}{lllll}
\hline & Environmental knowledge & Waste categorization & Livestock captivity & Sewage treatment \\
\hline Average male & 0.27 & 0.57 & 0.18 & 0.11 \\
Score female & 0.30 & 0.71 & 0.29 & 0.26 \\
Significance $(\alpha)$ & 0.12 & $0.07^{* *}$ & $0.02^{* * *}$ & $0.06^{*}$ \\
\hline
\end{tabular}

******, show significance at $1 \%, 5 \%$, and $10 \%$, respectively, the same below.

that education level is not significantly related to the four variables (Table 4). Moreover, education level was weakly related to farmers' perceptions of environmental renovation policies and skills and was not related to the other three behavior variables. The group with higher education level has more ways to master all aspects of knowledge and have better abilities to act. These conclusions and our prior assumptions have a significant difference. Through questionnaires and live interviews, the research group thought that farmers' rural living environment renovation perceptions mainly came from government propaganda and interpersonal communication. Moreover, the response action correlates not only with farmers' perceptions but also with policies on rural infrastructure construction government incentives and supervision, regional collective action, environmental protection team, and other factors.

4). Income level. For the analysis of the related coefficient between the four variables of farmers' household income level and environmental renovation perceptions, waste categorization and collection behavior, livestock captivity, and domestic sewage treatment were conducted. Moreover, the comprehensive score ratio of the four variables was obtained at different income levels. The results (Table 5, Figure 4) shows that a significant positive correlation exists among the income level and the three variables of the rural living environment perceptions, waste categorization, and collection behavior and domestic sewage treatment. Farmers' household income and living environment awareness, waste categorization and centralized behavior, and domestic sewage treatment behavior correlated strongly with correlation coefficients of $0.468,0.390$, and 0.513 , respectively.

Farmers' household income and livestock captivity behavior correlated weakly with a correlation coefficient of 0.104 . This finding indicated that farmers' household income level is related to their living environment renovation perceptions. Behaviorists reflect that recently, given increasing farmer income level, farmers will pay increasing attention to the rural living environment. Under the right guidance of the government, groups with higher income levels may use spontaneous response behavior in a particular region.

The average score ratio of the four variables in different income groups was further calculated. The results showed that (1) the group of farmers whose household income is under $\$ 2,282.68$ apparently lacks a behavioral response to the rural living environment renovation policy and knowledge. This group is mostly farming-based consumers, mainly spending on food and medical cost. They are not sensitive to the living environment, government policies, and other external information. They have a wait-to-see mood and are psychologically dependent on the living environmental behavioral response. (2) The living environment perceptions, domestic sewage treatment behavior, waste categorization, and concentrated

Table 4 - Correlation between educational level and farmers' perceptions and behavioral response variables.

\begin{tabular}{lcccc}
\hline & Environmental knowledge & Waste categorization & Livestock captivity & Sewage treatment \\
\hline Education level & 0.108 & 0.09 & 0.203 & 0.176 \\
\hline
\end{tabular}


Table 5 - Correlation between household income level and farmers' perceptions and behavioral response variables. Items on living environment awareness.

\begin{tabular}{|c|c|c|c|c|}
\hline & Environmental knowledge & Waste categorization & Livestock captivity & Sewage treatment \\
\hline Household income & $0.468^{* *}$ & $0.390^{*}$ & 0.104 & $0.513^{* *}$ \\
\hline
\end{tabular}

behavior, and household income of farmers increase monotonically. When their household income was between $\$ 2282.68$ and $\$ 11530.75$ the score ratio of waste categorization and collection scoring rapidly increases. At the present, $90.7 \%$ of the farmers have household income between \$2,282.68 and $\$ 11,530.75$, reflecting that in the action of farmers, waste categorization and concentrated behavior are likely to reach the support and response of farmers. Domestic sewage treatment behavior showed slow growth in the first stage of income growth. However, when the farmers' household income is over $\$ 11,530.75$, the score ratio of their domestic sewage treatment behavior significantly increased because sewage treatment requires considerable upfront fixed investment. At a household income of less than $\$ 11,530.75$, farmers do not have sufficient funds for sewage-processing pipeline and facility investment. Furthermore, their livestock captivity behavior and overall family income showed an inverted "U" shape, mainly because of the low proportion of high-income families to livestock captivity in rural areas.
Correlation test of farmers perceptions and behavioral response

A positive and rational reasonable response to the comprehensive renovation of the rural living environment was established on the basis of farmers' policy perceptions and renovation skills on rural living environment renovation. As long as farmers understand the status of rural living environment pollution and rural environmental renovation policies and methods, they can actively participate in a rural comprehensive renovation. By the analysis of the four variables of farmers' environmental awareness level, waste categorization and collection, livestock captivity and domestic sewage treatment behavior (Table 6), farmers' environmental perception level and the three variables of waste categorization and collection, livestock captivity, sewage treatment have a significant effect, which is more obvious in waste categorization and collection, followed by livestock captivity and sewage treatment behavior, with correlation coefficients of $0.55,0.24$, and 0.20 , respectively. Thus, by the calculation method of farmers' comprehensive response behavior

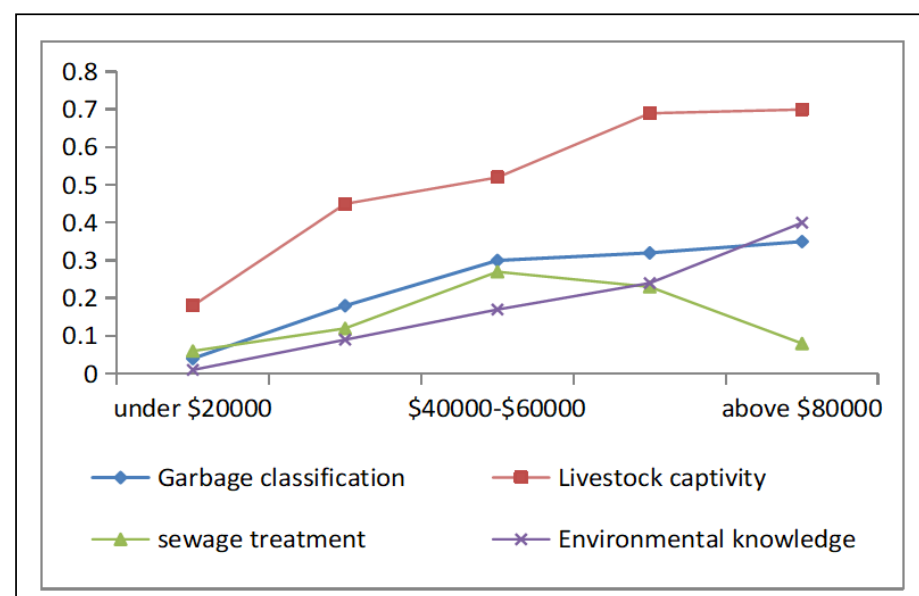

Figure 4 - Correlation between household income level and each perception and behavioral response variables as figure 1 . 
Table 6 - Correlation between rural environment perception degree and three behavioral responses.

\begin{tabular}{|c|c|c|c|c|}
\hline & Environmental knowledge & Waste categorization & Livestock captivity & Sewage treatment \\
\hline Recognition level & $0.55^{* *}$ & $0.24^{*}$ & $0.20^{*}$ & $0.38^{*}$ \\
\hline
\end{tabular}

(V6), the correlation coefficient between farmers' comprehensive response behavior and farmers' perception level is 0.38 . The results show that if the farmers in the sample areas have a high degree of awareness on the status of the rural environmental pollution and the rural living environment renovation policies and methods, their behavioral response will be more active and vice versa.

\section{DISCUSSION AND CONCLUSION}

The basic situation and some general features of farmers' perceptions and behavioral response in the comprehensive renovation of the rural living environment are preliminarily analyzed through live interviews and questionnaires in the major riceproducing areas in Dongting Lake Wetland Reservation. The following relevant conclusions are obtained.

1. Farmers have increased environmental awareness, showing that they have realized the importance of a beautiful and clean-living environment in rural areas in their production and life. However, farmers are not familiar with the rural living environment renovation goals, content, and measures of the government. Their knowledge of the living environment renovation is far from ideal. To improve farmers' living environmental renovation capabilities, the government should focus on mobilizing publicity through posters, banners to policy advocacy (leaflets, village regulations, and non-governmental agreements), action skills, and knowledge publicity. A large development space continues to exist in the sample regions. Farmers' increased environmental awareness shows that ordinary farmers can often actively take the initiative to participate in the comprehensive renovation of rural living environment with accurate guidance accurately and timely propaganda even though farmers have a high awareness level of the rural living environment comprehensive renovation. The general level of behavioral response of farmers affected by traditional behavioral habits, wait-andsee mood, and dependence awareness should be improved. The highest level of their responses is observed in waste categorization and collection behavior followed by livestock captivity and domestic sewage treatment. In the surveyed areas, the sound infrastructure construction of rural environmental protection, the able village committee, and regional (route) concentrated behavior are the external factors affecting farmers' response behavior, regions with improved external factors, and farmers' behavioral response. The response degree of farmers to living environment protection is higher in areas with better external factors.

2. The general level of rural living environment perceptions and behavioral response initially declines, increases and decreases again from teenagers to elderly farmers. The best perceptions and response degrees are from young adults aged 35-55 years, whereas the worst perceptions come from young and old farmers. Therefore, strengthening targeted publicity, education, and behavior guidance of young and old farmers is necessary to improve their overall perception level and action response. For young people aged 20-35 years, we should focus on their weak social sense of participation and free ride psychology, strengthen their sense of social and family responsibilities and guide them to establish good habits and sets of behavior. People aged over 55 years comprise the most vulnerable groups of the rural economy and society. The five-guarantee system and the minimum living standard security system should be implemented. Village committees should focus on their living and production conditions so that they can be liberated from heavy manual labor and cared for by society.

3. In the study areas, the level of female perceptions and response to the comprehensive renovation of the rural environment is higher than that of male perceptions and response, especially for the three action response parameters. Women are sensitive to the health status of the living environment in rural households, and health protection work is mostly provided by women. Therefore, the environmental health renovation policies and skills of women in the study areas should be strengthened to improve the farmers' responsiveness and level. 
4. For the education level and farmers' living environment renovation and skills, the three types of behavior are not significantly related. With high awareness of the living environment, farmers' familiarity with the living environment renovation skills and government policies mainly comes from government propaganda and interpersonal propagation, which are closely related to the living environment skills. Thus, some sample villages use students' environmental health collective clean-up behavior, collective action in key areas (or along rural traffic arteries), environmental health inspection, and assessment activities, which are effective in shaping cultural atmosphere and promoting interpersonal propagation.

Farmers' household income and perceptions, waste categorization and collection, and domestic sewage treatment behavior have a significantly positive correlation. Farmers' household income and livestock captivity behavior presents an inverted "U" shape. Farmers whose total household income is under $\$ 2,882.69$ are not sensitive to the living environment, government policies, and other external information. Their degree of perceptions and behavioral response to comprehensive renovation of the rural living environment are ideal. Farmers whose total household income is between $\$ 2,882.69$ and $\$ 11,530.75$ have the fastest increase in the degree of response to waste categorization and collection behavior with respect to an increase in income. Under the correct government guidance, farmers are likely to participate in waste categorization and collection. Farmers with income within $\$ 2,882.69$ and $\$ 11,530.75$ have a low response to sewage-processing behavior and slow growth. However, when household income is over $\$ 11,530.75$, farmers' active response ratio is significantly improved. They are willing to spend a certain amount of funds for sewage treatment facilities within the family courtyard. These data can provide a basis for the government to start a sewage treatmentprocessing project with an enhanced economic base of peasant settlements.

6. Farmers' skills perception to policies and the living environment renovation remarkably influences the three ways of behavior response. Farmers have the closest relationship with waste categorization and collection behavior. A better familiarization with policy and renovation skills for the living environment provides a more active behavioral response to farmers. Interior factors, such as rural infrastructure, are determined. In addition to relatively determined external factors, such as infrastructure construction in rural areas, cadre work in a countryside, topic-targeted meetings, and public surveillance are effective internal ways to improve the perception level of farmers in the rural living environment, renovation policies, and renovation skill.

\section{DECLARATION OF CONFLICTS OF INTERESTS}

The authors declare no conflict of interest. The founding sponsors had no role in the design of the study; in the collection, analyses, or interpretation of data; in the writing of the manuscript, and in the decision to publish the results.

\section{ACKNOWLEDGEMENTS}

This thesis would not have been possible without the consistent and valuable reference materials that I received from Dr. Deng whose insightful guidance and enthusiastic encouragement in the course of my shaping this thesis definitely gain my deepest gratitude.

\section{AUTHORS' CONTRIBUTIONS}

All authors contributed equally for the conception and writing of the manuscript. All authors critically revised the manuscript and approved of the final version.

\section{REFERENCES}

AJZEN I. The theory of planned behavior. Organizational behavior and human decision process, v.50, n.2, p.179-211, 1991. Available from: <https://www.sciencedirect.com/science / article/abs/pii/>. Accessed: Dec 3, 1991. doi: 10.1016/07495978(91)90020-T.

AJZEN I. The theory of planned behavior: reactions and reflections. Psychology and health, v26, n.9, p.1113-1127, 2011. Available from: <https://www.tandfonline.com/doi/full/10 $.1080 / 08870446.2011 .613995>$. Accessed: Aug. 09, 2011. doi: 10.1080/08870446.2011.613995.

BELL A R et al., Scaling up pro-environmental agricultural practice using agglomeration payments: Proof of concept from an agent-based model. Ecological Economics, v.126, n.126, p.32-41, 2016. Available from: <https://www.sciencedirect.com/science/ article/abs/pii/S0921800915302299>. Accessed: Jun. 16, 2016. doi: 10.1016/j.ecolecon.2016.03.002.

GU XINMEI, SHUISHUYAN. To get farmers' Further Participation in the Comprehensive Improvement of Rural Environment. Journal of Shengyang College of Education, v.10, p.96-99, 2008. Available from; <http://en.cnki.com.cn/Article_en/ CJFDTotal-SYXX200805030. him>. Accessed: Oct. 9, 2008. doi: 1008-3863 (2008) 05-0096-04.

GUAGNANO G.A. S et al.,.. Influences on attitude-behavior relationships: A natural experiment with recycling. Environment and behavior, v.27, n.5, p.669-718, 1995. Available from: <https:// journals.sagepub.com/doi/abs/10.1177/0013916595275005>. Accessed: Sep. 1, 1995. doi: 10.1177/0013916595275005. 
HEBERER T. Environment of Citizenship in Urban China or Authoritarian Communitarianism Neighborhood development, community participation, and autonomy. Journal of Contemporary China, v.18, n.61, p.491-515, 2009. Available from: <https:// www.tandfonline.com/doi/full/10.10 80/10670560903033786>. Accessed: Aug. 12, 2009. doi:10.1080/10670560903033786.

HU RIFA, HUANG JIKUN, LI LIQIU. Chinese Agricultural Extension: Current Situation, Problems and Countermeasures. Management World, v.5, p.50-57, 2004. Available from: $<$ https:// kns.cnki.net $/ \mathrm{KCMS} /$ detail/detail.aspx ?dbcode $=$ CJFQ\&dbname $=$ CJFD2004\&filenam>. Accessed: May, 20, 2004. doi: 10.19744/j. cnki.11-1235/f.2004.05.008.

HUANG JIKUN, HU RIFA, SONG JUN. Agricultural Technology From Production to Adoption-the Behavior Comparison of Government, Scientist, Employees for ATE and Farmers. Studies in Science of Science, v.one, p.27-31, 1999. Available from: $<$ https:// kns.cnki. net/KCMS/detail/detail. aspx?dbcode=CJFQ\&name $>$. Accessed: Mar. 30, 1999.

KONG XIANGZHI, FANG SHONGHAI. Analysis of the Effect of Household Endowments on the Agricultural Technology Adoption Decision in West China. Economic Research Journal, v.3, p.85-95, 2004. Available from: <https://kns.cnki.net/KCMS/ detail/detail.asp ? dbcode $=$ CPFD\&name $=$ CPFD091 4\&filename $>$. Accessed Oct. 24, 2004.

KOSTKA, GENIA, MOL. Implementation and participation in China's local environmental politics: Challenges and innovations. Journal of Environmental Policy \& Planning, v.15, n.1, p.3-16, 2013. Available from: <https://www.researchgate. net/ publication/235987584>. Accessed: Mar. 26, 2013. doi: 10.1080/1523908X.2013.763629.

LIU K, HUISINGH D. Farmers' perceptions, and adaptation behavior concerning land degradation: A theoretical framework and a case-study in the Qinghai-Tibetan Plateau of China. Land Degradation \& Development, v.29, n.8, p.2460-2471, 2018. Available from: <https://onlinelibrary.wiley.com/doi/ abs/10.1002/ldr.3011>. Accessed: May, 15, 2018. 26, 2013 doi:10. 10 02/ldr.3011.

LU H., XIE H. Impact of changes in labor resources and transfers of land use rights on agricultural non-point source pollution in Jiangsu Province, China. Environment Management, v.13, p.134-140, 2018. Available from: <https://www.sciencedirect. com/science/article/>. Accessed: Feb. 1, 2018. doi: 10.1016/j. jenvman.2017.11.033.

LV JUN, LIU LIMEI. An Investigation of Farmers' Environmental Perception Level in Tourism development Grassland. Chinese Rural Economy, v.1, p.40-49, 2008. Available from: $<$ https:// kns.cnki.net/KCMS/detail/detail.aspx?dbcode=CJFQ\&dbname $>$. Accessed: Jan. 30, 2008.

MAO CHENGXING. Study on antibiotic Prophylactic Use Behavior and Influencing Factors of Livestock and Poultry Breeding Farms and Households from Risk Cognitive Perspective. Asian Agricultural Research, v.10, n.4, 2018. Available from: $<$ https://ideas.repec.org/a/ags/asagre/276133.html $>$. Accessed: Apr. 10, 2018. doi: 10.22004 / ag.econ.276133.

MARR, E.J, HOWLEY, P. The accidental environmentalists: Factors affecting farmers' adoption of pro-environmental activities in England and Ontario. Rural Study, v.68, p.100-111, 2019. Available from: <https://www.sciencedirect.com/science/article/ abs/pii/S0743016718304133>. Accessed: May 14, 2019. doi: 10.1016/j.jrurstud.2019.01.013.

MORAIS, M., BORGES, J.A.R. Using the reasoned action approach to understand the Brazilian successors intention to take over the farm. Land use policy, v.71, p.445-452, 2018. Available from: $\quad<$ https://www.sciencedirect.com/science/article/abs/pii/ S0264837717301564>. Accessed: Feb. 13, 2018. doi: 10.1016/j. landusepol.2017.11.002.

QI X, WANG RY, LI J, ZHANG T, LIU L,. Ensuring food security with lower environmental costs under intensive agricultural land use patterns: A case study from China. Journal of Environmental Management, v.213, p.329340, 2018. Available from: <https:/www.researchgate.net/ publication/323557511_Ensuring_food_security_with_lower_ environmental_costs_under_intensive_agricultural_land_use patterns_A_case_study_from_China $>$. Accessed: May, 1, 2018. doi:10.1016/j.jenvman. $2018 . \overline{0} 2.048$

SULLIVAN J, XIE L. Environmental activism, Social Networks, and the Internet $[\mathrm{J}]$. The China Quarterly, v,198, n.198, p.422-432, 2009. Available from: <https://www.cambridge. org/core/journals/china-quarterly/article/abs/environmentalactivism-social-networks-and-the-internet/7D4C5049BF98574 E23138AE688A8CD46>. Accessed: Jun. 4, 2009. doi:10.1017/ S0305741009000381.

TANG, BOSIN, SIUWAI Wong. Social impact assessment and public participation in China: A case study of land requisition in Guangzhou. Environmental Impact Assessment Review, v.28, n.1, p.57-72, 2008. Available from: <https://www.sciencedirect. com/ science/article/abs /pii/S019 592550 7000443>. Accessed: Jan. 11, 2007. doi: 10.1016/j.eiar.2007.03.004

WANG Y, LIANG J, YANG J. Analysis of the environmental behavior of farmers for non-point source pollution control and management: An integration of the theory of planned behavior and the protection motivation theory. Journal of Environmental Management. v.237, p.15-23, 2019. Available from: $\quad<$ https://www.sciencedirect.com/science/article/pii/ S030147971930221X>. Accessed: May, 1, 2019. doi: 10.1016/j. jenvman. 2019.2019.02.070.

XIE. Environmental governance and public participation in rural China. China Information, v.30, n.2, p.188-208, 2016. Available from: <https://journals.sagepub.com/doi/abs/10.1177/ 0920203X166538 80?>. Accessed: Jun. 30,2016. doi: $10.1177 / 0920203 \times 16653880$.

ZHOU JIN. An Investigation and Analysis of Environmental Awareness of Peasants in Jiangsu Province. China Rural Survey, v.3, p.47-52, 2009. Available from: <http://en.cnki.com.cn/ Article_en/CJFDTotal-ZNCG200903008.htm>. Accessed: Sep. 18,2009 .

ZHU QIZHEN. An Investigation and Research of One insufficiently Attracted Question about Farmers' Environmental Perception. The world of Survey and Research, v.one1, p.28-31, 2001. Available from: $<$ https://kns.cnki.net/KCMS/detail/detail. aspx?dbcode $=$ CJFQ\&dbname $>$. Accessed: Jan. 10, 2001. doi: 10.13778/j.cnki.11-3705/c.2001.01.008 